\title{
OPTIMALISASI GUIDED DISCOVERY LEARNING UNTUK MENINGKATKAN SELF-CONFIDENCE SISWA DALAM PEMBELAJARAN MATEMATIKA
}

\author{
Cinta Adi Kusumadewi dan Raden Rosnawati \\ Pendidikan MatematikaProgram Pascasarjana, Universitas Negeri Yogyakarta \\ email: cintaadi.2018@student.uny.ac.id
}

\begin{abstract}
Abstrak
Penelitian ini dilakukan untuk mengetahui upaya optimalisasi pendekatan guided discovery learning untuk meningkatkan self-confidence siswa. Jenis penelitian ini merupakan penelitian tindakan berdasarkan model Kemmis dan McTaggart. Penelitian ini dilaksanakan terhadap 28 siswa kelas VII di level sekolah menengah pertama. Pengambilan data dilakukan dengan angket self-confidence dengan pengisian skala likert 1-5 sebelum dan setelah tindakan. Butir pernyataan pada angket merupakan penjabaran dari lima aspek self-confidence, yaitu keyakinan terhadap kemampuan matematis, keyakinan terhadap matematika, sikap optimis, rasional dan realistik, serta ketegasan dalam tindakan. Untuk mengetahui tingkat self-confidence siswa melalui pendekatan guided discovery learning. Teknik analisis data menggunakan persentase dari rata-rata hasil skor kumulatif pada setiap siklus. Tindakan dengan pendekatan guided discovery learning dilakukan secara bersiklus hingga mencapai peningkatkan self-confidence siswa kelas VII. Hasil penelitian menunjukkan bahwa pendekatan guided discovery learning dapat meningkatkan self-confidence siswa kelas VII dengan optimalisasi pada setiap langkah pembelajaran. Di samping itu, adanya peran guru sangat penting dalam meyakinkan siswa terhadap langkah-langkah penyelesaian melalui cross-check/evaluation sesuai kaidah penyelesaian.
\end{abstract}

Kata kunci: self-confidence, guided discovery learning, matematika

\section{OPTIMIZATION GUIDED DISCOVERY LEARNING TO IMPROVE STUDENTS' SELF-CONFIDENCE IN MATHEMATICS LEARNING}

\begin{abstract}
This study was conducted to optimize the guided discovery learning approach to increase students' self-confidence. This study is an action research based on the Kemmis and McTaggart model. This study was conducted on 28 grade VII students at the junior high school level. The data were collected using a self-confidence questionnaire in a Likert scale of $1-5$ before and after the implementation. The statement items in the questionnaire describe five aspects of self-confidence, namely belief in mathematical abilities, belief in mathematics, optimism, rational and realistic attitudes, and assertiveness in action. Then, to determine the level of student self-confidence, the guided discovery learning approach was used. The data analysis technique used a percentage of the average cumulative score in each cycle. The action with the guided discovery learning approach was carried out on a cycle basis to achieve an increase in self-confidence of class VII students. The results show that the guided discovery learning approach could increase the self-confidence of class VII students by optimizing each step of the learning. In addition, teacher's role is crucial in convincing students of the steps for completion through cross-check/evaluation according to the rules of completion.
\end{abstract}

Keywords: self-confidence, guided discovery learning, mathematics 


\section{PENDAHULUAN}

Self-confidence (kepercayaan diri) merupakan kepercayaan terhadap kemampuan diri dalam menggerakkan motivasi yang dimunculkan dalam tindakan untuk mencapai suatu tujuan tertentu. Self-confidence adalah keyakinan tentang kemampuan untuk menyelesaikan masalah dan berpikir tentang diri sendiri. Pentingnya self-confidence tercantum pada Permendikbud Nomor 21 Tahun 2016 yang menyebutkan bahwa di dalam pembelajaran tidak hanya fokus pada pencapaian tujuan kognitif, namun terdapat pencapaian yang bersifat afektif. Hal ini diperkuat dengan Permendikbud Nomor 68 Tahun 2013 yang menyebutkan salah satu kompetensi dasar matematika yaitu memiliki kepercayaan diri (self-confidence).

Siswa penting memiliki selfconfidence. Studi internasional The Trends in International Mathematics and Science Study (TIMSS) (2012) menyertakan pengukuran terkait kemampuan ini. Hasil studi tersebut mencatat hanya 3\% siswa Indonesia yang memiliki self-confidence tinggi, sedangkan sebanyak $45 \%$ termasuk dalam kategori siswa dengan self-confidence rendah dalam matematika.

Self-confidence merupakan ukuran nonkognitif yang lebih baik untuk melihat gambaran prestasi siswa dibandingkan dengan ukuran nonkognitif lainnya (Sritresna, 2017). Hal ini memberikan gambaran bahwa tinggi rendahnya selfconfidence siswa sejalan dengan prestasi dan kemampuan matematikanya. Siswa dengan self-confidence tinggi dalam belajar matematika memiliki kemampuan lebih baik daripada siswa dengan self-confidence lebih rendah (May \& Fray, 2010).

Lauster (Ghufron \& Risnawati, 2012, p. 35-36) mengungkapkan bahwa aspekaspek self-confidence meliputi: keyakinan terhadap kemampuan diri sendiri, optimis, objektif, bertanggung jawab, dan rasional, serta dan realistis. Preston (2007, p. 14) menyebutkan lima aspek pada selfconfidence yaitu kesadaran diri, niat, berpikir positif dan rasional, berpikir kreatif saat bertindak dan bertindak. Oleh sebab itu, pada penelitian ini aspekaspek self-confidence dalam pembelajaran matematika di antaranya: keyakinan terhadap kemampuan matematika, yaitu sikap positif tentang kemampuan diri pada bidang matematika; keyakinan terhadap matematika, yaitu sikap positif terhadap karakteristik mata pelajaran matematika; sikap optimis, yaitu sikap seseorang yang terwujud karena berpandangan baik dalam menghadapi segala hal tentang diri dan kemampuannya; berpikir rasional dan realistik dalam menyelesaikan masalah matematika; dan ketegasan dalam bertindak, yaitu sikap tidak ragu-ragu dalam bertindak, termasuk sikap mengambil keputusan dalam menyelesaikan masalah.

Berdasarkan observasi ditetapkan bahwa self-confidence sebagai masalah yang dihadapi oleh guru di kelas tersebut. Hasil observasi kelas dijumpai beberapa temuan, seperti banyak siswa yang ragu dengan jawaban dari permasalahan matematika yang diberikan, sehingga mereka berulang kali bertanya kepada guru untuk memastikan langkah penyelesaian dan solusi jawaban. Beberapa siswa lain bersikap pasif ketika mengalami kesulitan dan cenderung mengandalkan jawaban teman. Akibatnya, banyak siswa yang belum berani menyatakan pendapatnya secara mandiri di depan kelas mengenai jawaban atas soal-soal yang diberikan oleh guru. Tidak hanya itu, selama proses pembelajaran masih dijumpai siswa tidak berani untuk menanyakan sesuatu yang sulit untuk mereka pahami. Mereka lebih banyak menerima informasi daripada mencari atau menemukan pengetahuan melalui proses belajarnya. 
Hal ini diperkuat dengan hasil angket data awal mengenai self-confidence dengan hasil nilai rata-rata 86,43 pada rentang 72,80 dan 95,20; yang berada pada kategori sedang. Secara detail, $18 \%$ dari 28 siswa memiliki self-confidence rendah, $68 \%$ siswa berada pada kategori sedang, dan sisanya $(14 \%)$ berada pada kategori sangat rendah. Berdasarkan data tersebut menunjukkan bahwa kurangnya self-confidence siswa kelas VII E dalam belajar matematika.

Salah satu upaya untuk dapat meningkatkan self-confidence siswa adalah melalui pembelajaran aktif (Smith, Grundmann, \& Li, 2018). Pembelajaran aktif ditandai dengan keterlibatan siswa yang tinggi, menempatkan kepentingan yang signifikan pada keterpusatan peserta didik (Cattaneo, 2017). Salah satu pendekatan pembelajaran aktif adalah discovery learning (Ott, Carpenter, Hamilton, \& LaCourse, 2018). Bruner menyatakan bahwa discovery learning adalah suatu pendekatan yang memberikan kesempatan kepada peserta didik untuk menemukan prinsip-prinsip dasar secara mandiri (Liestya, Muchlis, \& Agustinsa, 2020) sehingga mereka tidak hanya menghafal prinsip-prinsip tersebut (Westwood, 2008, p. 28). Model pembelajaran ini memberikan kesempatan pada siswa untuk belajar sendiri, mendorong siswa untuk berpikir sendiri, dan mengetahui cara membangun pengetahuan.

Berkaitan dengan hal itu, model guided discovery learning merupakan model discovery learning yang dimodifikasi. Dalam pelaksanaannya, guru memberikan beberapa petunjuk pada peserta didik saat belajar matematika. Model pembelajaran guided discovery learning, siswa diberikan kesempatan untuk aktif mengkonstruksi pengetahuannya sendiri dengan bantuan bimbingan dari guru. Guided discovery learning lebih menekankan pada proses penemuan konsep siswa melalui bimbingan guru (Muhammad \& Karso, 2018, p. 109) sehingga dalam pembelajaran ini guru hanya sebagai fasilitator siswa untuk mengkonstruksi pengetahuan siswa dan mencapai hasil yang optimal.

Model guided discovery learning mengarahkan siswa ikut aktif berpartisipasi dalam pembelajaran sehingga dapat memperkuat konsep belajar (Mahanani, Rahayu, \& Fajaroh, 2019) dan membantu siswa dalam meningkatkan keterampilan pemecahan masalah matematika (Jana, Anisa, \& Fahmawati, 2020). Selain itu, penelitian Hasugian (2018) memiliki hasil bahwa model guided discovery learning efektif ditinjau dari prestasi belajar siswa. Model ini dapat meningkatkan peningkatan rasa percaya diri siswa melalui model pembelajaran penemuan terbimbing; yaitu sebanyak $80,83 \%$ siswa memiliki rasa percaya diri dengan kategori tinggi setelah diupayakan melalui guided discovery learning (Kurniasih, 2016; Tran, Nguyen, Bui, \& Phan, 2014).

Langkah-langkah pada guided discovery learning yaitu: pemberian rangsangan informasi; identifikasi masalah, pengumpulan data; pengolahan data; pemeriksaan kembali; dan pembuatan kesimpulan (Syah, 2014). Aktivitasaktivitas siswa pada sintaks guided discovery menimbulkan sikap positif dan yakin dalam pemecahan masalah matematika dan pendekatan ini dapat meningkatkan self-confidence (Hapsari, 2011). Secara rinci keterhubungan masing-masing aspek pada self-confidence dan aktivitas pada langkah-langkah guided discovery learning disajikan pada Gambar 1.

\section{METODE}

Metode penelitian yang digunakan adalah penelitian tindakan kelas dengan model penelitian dari Kemmis dan McTaggart (Hopkins, 2008, p. 51). Model 
Gambar 1. Keterkaitan antara Guided Discovery Learning dengan SelfConfidence

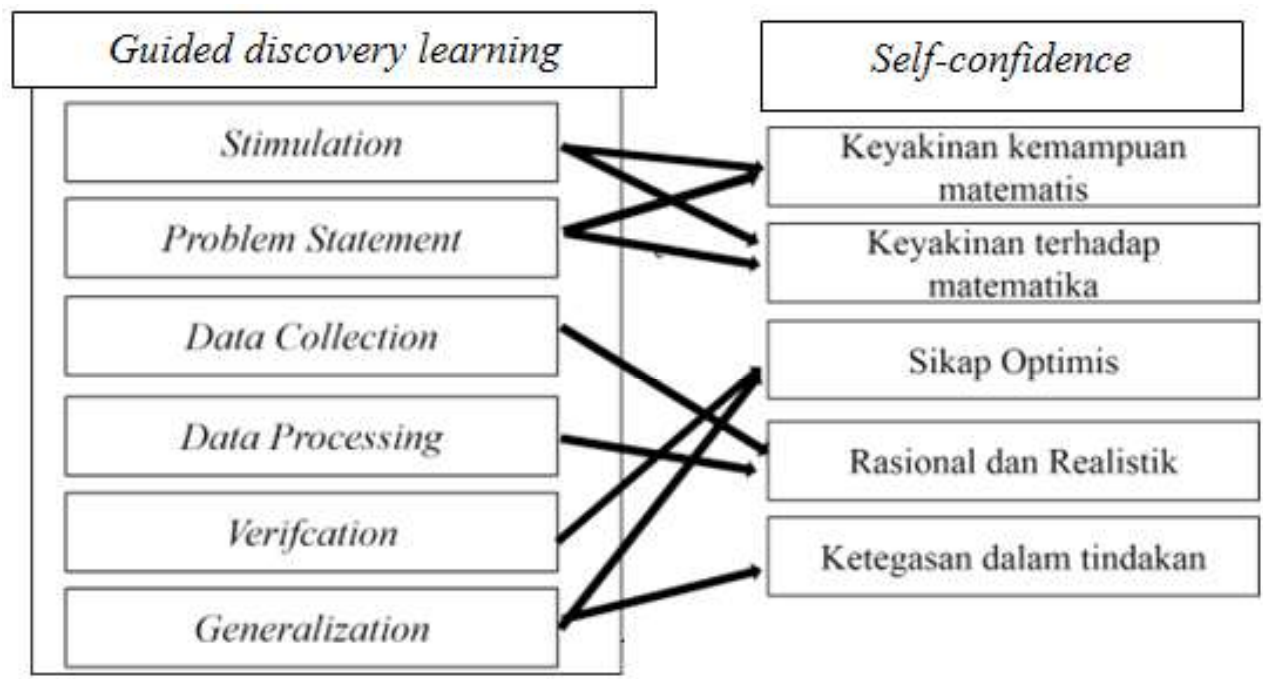

penelitian ini bersiklus dengan tahapan: perencanaan, tindakan, pengamatan, dan refleksi. Penelitian ini dilaksanakan terhadap 28 siswa kelas VII di SMP Negeri 2 Yogyakarta.

Rancangan utama tindakan berupa pembelajaran pendekatan guided discovery learning dengan langkah-langkah sebagai berikut: pemberian rangsangan informasi, pemberian masalah, pengumpulan data, pengolahan data, pemeriksaan kembali, dan pembuatan kesimpulan. Perbaikan rancangan siklus berikutnya dilakukan berdasarkan hasil refleksi.

Instrumen yang digunakan pada penelitian ini terdiri dari lembar observasi keterlaksanaan pembelajaran dan angket self-confidence. Lembar observasi ini digunakan sebagai alat untuk menilai keterlaksanaan pembelajaran agar sesuai dengan Rencana Pelaksanaan Pembelajaran (RPP) pendekatan guided discovery learning dan Lembar Kegiatan Peserta Didik (LKPD). Lembar observasi ini berisi tentang 38 butir pernyataan yang meliputi kegiatan guru (KG) dan kegiatan siswa (KS) yang terdiri dari 3 bagian, yaitu pendahuluan (apersepsi), inti pendekatan guided discovery learning, dan penutup.

Angket self-confidence dari 31 butir pernyataan dengan pengisian skala likert 1-5 pada setiap butir pernyataan. Butir pernyataan tersebut merupakan penjabaran dari lima aspek self-confidence, yaitu keyakinan terhadap kemampuan matematis, keyakinan terhadap matematika, sikap optimis, rasional dan realistik, serta ketegasan dalam tindakan. Kemudian, untuk mengetahui tingkat self-confidence siswa melalui pendekatan guided discovery learning.

Teknik analisis data menggunakan persentase dari rata-rata hasil skor kumulatif pada setiap siklus. Skor hasil pengisian angket siswa dianalisis dengan cara mengkonversikan menjadi data kualitatif dengan tabel konversi skor penilaian menurut Azwar (2012, p. 148) 
dapat dilihat pada Tabel 1. Analisis hasil tes prestasi belajar pada setiap siklus tetap dilakukan agar tujuan utama pembelajaran matematika tetap dicapai. Hasil tes prestasi belajar dihitung dan ditentukan secara persentase banyaknya siswa yang tuntas melampaui batas kriteria ketuntasan minimum $(\mathrm{KKM}=65)$.

Tabel 1

Kriteria Angket Self-confidence Siswa

\begin{tabular}{cc}
\hline Interval Skor & Kategori \\
Kuantitatif & \\
\hline $\boldsymbol{x} \geq 117,60$ & Sangat Tinggi \\
$95.20<x<117.60$ & Tinggi \\
$72.80<x \leq 95.20$ & Sedang \\
$50.40<x \leq 72.80$ & Rendah \\
$x \leq 50.40$ & Sangat Rendah \\
\hline
\end{tabular}

Indikator keberhasilan pada penelitian ini adalah apabila memenuhi kriteria: hasil tes prestasi belajar siswa yang mencapai kriteria ketuntasan minimal $(\mathrm{KKM}=65)$ paling sedikit $75 \%$, skor rata-rata selfconfidence siswa meningkat dengan minimal mencapai kategori tinggi, dan keterlaksanaan pembelajaran mencapai nilai minimal $80 \%$.

\section{HASIL PENELITIAN DAN PEMBAHASAN}

Penelitian ini dilaksanakan sebanyak 2 siklus yang masing-masing siklus terdiri dari 3 kali pertemuan pembelajaran. Setiap siklus mencakup: tahap perencanaan, tahap pelaksanaan, pengamatan, dan refleksi. Siklus I dimulai pada tanggal 28 Oktober 2019 dengan durasi 6 x 40 menit dan $2 \times$ 40 menit untuk tes pretasi belajar siklus I.

Pada tahap perencanaan siklus I, peneliti menyusun instrumen awal, yaitu RPP dan LKPD yang disusun dengan sintaks guided discovery learning. Selain itu, disiapkan instrumen berupa soal tes prestasi belajar, angket self-confidence siswa, dan lembar observasi keterlaksanaan pembelajaran. Semua instrumen terlebih dahulu dikonsultasikan dengan expert judgment agar valid untuk digunakan. Setelah semua instrumen sudah siap, dilanjutkan ke tahap pelaksanaan.

Tahap pelaksanaan, peneliti bertindak sebagai guru yang melaksanakan pembelajaran dengan pendekatan discovery learning. Rangkaian pembelajaran dilaksanakan sesuai dengan sintaks pada rancangan RPP yang dilengkapi dengan LKPD. Adapun proses pembelajaran guided discovery learning dilakukan dengan diskusi secara berkelompok yang masingmasing kelompok terdiri atas 4 siswa.

Pada tahap pengamatan, observer bertugas mengamati keterlaksanaan pembelajaran dengan pendekatan guided discovery learning. Tahap pelaksanaan dan pengamatan ini dilakukan secara bersamaan, guru matematika bertindak sebagai observer dari pelaksanaan pembelajaran. Hasil observasi keterlaksanaan pembelajaran siklus I dapat dilihat pada Tabel 2 dan Gambar 2.

Tabel 2 menunjukkan bahwa keterlaksanaan pembelajaran pada bagian kegiatan siswa (KS) hanya mencapai $76,67 \%$ dengan target minimal $80 \%$. Hal ini menunjukkan bahwa keterlaksanaan pembelajaran pada kegiatan siswa belum tercapai. Menurut hasil observasi, ini disebabkan oleh beberapa siswa yang belum memberikan feedback sesuai harapan pada tahap pembelajaran.

Pada tahap refleksi siklus I, peneliti bersama kolabolator melakukan evaluasi terhadap hasil tes prestasi belajar siswa, hasil angket self-confidence siswa, dan keterlaksanaan pembelajaran. Evaluasi ini mencakup di setiap langkah pada guided discovery learning, yaitu stimulation, problem statement, data collection, data processing, verification, dan generalization. Berdasarkan Tabel 3, hasil tes prestasi 
Tabel 2

Hasil Keterlaksanaan Pembelajaran Siklus I

\begin{tabular}{lcc}
\multicolumn{1}{c}{ Aspek Penilaian } & Hasil & Keterangan \\
\hline Kegiatan Guru (KG) & $81,33 \%$ & Tercapai \\
Kegiatan Siswa (KS) & $76,67 \%$ & Belum Tercapai \\
\hline
\end{tabular}

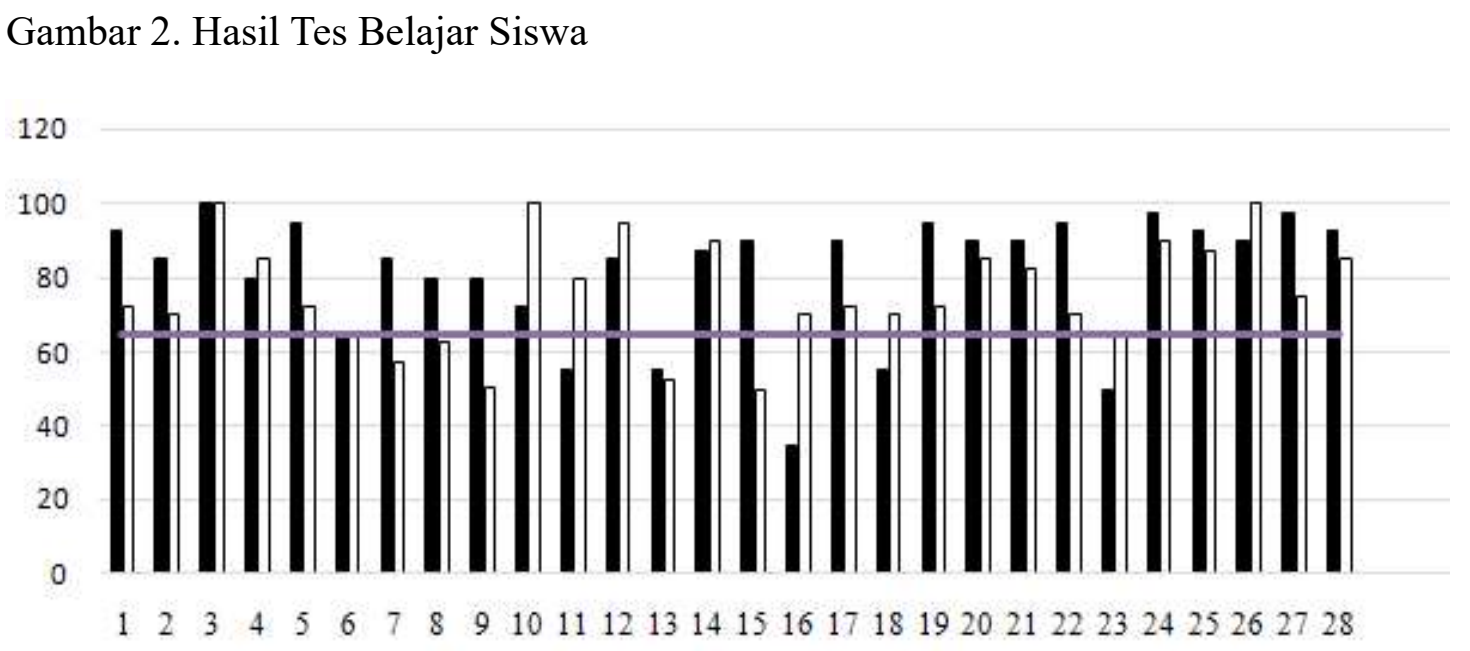

Siklus $1 \square$ Siklus $2 \longrightarrow$ KKM

Tabel 3

Hasil Belajar Siswa pada Siklus I dan Siklus II

\begin{tabular}{lcc}
\hline & Siklus I & Siklus II \\
\hline Skor Minimun & 35 & 50.5 \\
Skor Maksimum & 100 & 100 \\
Rata-rata & 75,36 & 81,5 \\
Ketuntasan & $22(79 \%)$ & $23(82 \%)$ \\
\hline
\end{tabular}

belajar siswa pada siklus I telah mencapai indikator keberhasilan yaitu $79 \%$ dari target keberhasilan minimal $75 \%$ dengan nilai rata-rata 75,36 . Sama seperti hasil tes prestasi belajar, self-confidence siswa telah mencapai target keberhasilan minimal yaitu berada pada kategori tinggi dengan nilai rata-rata 113,93 pada siklus I (Tabel 4 ). Akan tetapi, pembelajaran pada kegiatan siswa (KS) belum mencapai minimal target yang ditentukan sehingga dilakukan analisis lebih lanjut pada kegiatan siswa yang belum terlaksana. Kemudian, peneliti bersama kolaborator memberikan beberapa solusi yang dapat dilakukan pada pembelajaran siklus II untuk memperoleh hasil yang optimal meskipun self-confidence siswa telah mencapai target keberhasilan.

Pada tahap stimulation, sebagian besar siswa hendaknya mempunyai keinginan 
Tabel 4

Hasil Angket Self-Confidence Siswa

\begin{tabular}{lccc}
\hline & Prasiklus & Siklus I & Siklus II \\
\hline Rata-rata & 86,43 & 113,93 & 118,36 \\
Simpangan Baku & 10,84 & 11,37 & 9,83 \\
Kategori & Sedang & Tinggi & Tinggi \\
\hline
\end{tabular}

untuk menyelidiki masalah yang diberikan guru dan yakin dapat menyelesaikannya secara sederhana, baik menggunakan teknik trial and error maupun intuisi. Selain itu, pemberian stimulasi berupa permasalahan seharusnya dapat menimbulkan keyakinan siswa terhadap matematika, masalah matematika tersebut dapat diselesaikan. Fakta di lapangan, siswa merasa bingung dengan masalah yang disajikan sehingga siswa ragu-ragu untuk mengutarakan jawabannya. Banyak siswa tidak mampu menjawab masalah tersebut. Oleh karena itu, pada pembelajaran guru harus menjelaskan secara berulang permasalahan dengan bahasa yang mudah untuk mereka pahami.

Berdasarkan uraian di atas, peneliti yang bertindak sebagai guru bersama kolabolator melakukan evaluasi dan pemberian solusi atas masalah yang ditemukan. Solusi yang diberikan berupa pemberian masalah dengan model matematika intuitif pada pembelajaran pada siklus II. Solusi ini mampu membuat siswa mudah memahami permasalahan yang dimaksud sehingga siswa dapat memahami maksud dari permasahalan tersebut.

Pada tahap problem statement, ada beberapa kegiatan siswa yang belum terlaksana dengan baik. Hal ini dapat terjadi karena pada proses stimulation siswa tidak berhasil untuk memahami permasalahan yang diberikan. Selain itu, masih ditemukan sebagian besar siswa gagal untuk menemukan kata kunci dari suatu permasalahan. Akibatnya, siswa mengalami kesulitan untuk mengidentifikasi masalah dan merumuskan hipotesis dari permasalahan.

Untuk mengatasi hal tersebut, peneliti bersamaa kolabolator memberikan solusi perbaikan yang dapat dilakukan pada pembelajaran di siklus selanjutnya. Adapun solusi tersebut adalah pemberikan bimbingan secara klasikal di depan kelas mengenai tahapan mengidentifikasi masalah. Bimbingan ini bertujuan untuk membantu siswa dalam menemukan kata kunci dari masalah yang diberikan sehingga lebih mudah untuk dipahami.

Pada tahap data collection dan data processing, siswa mengalami kendala untuk mengumpulkan informasi dari masalah yang diberikan. Hal ini terjadi karena siswa telah mengalami kesulitan dalam memahami permasalahan. Kendala ini dijumpai saat sebagian siswa bertanya kepada guru yang sedang memantau secara berkeliling tentang cara untuk menemukan informasi dari permasalahan yang diberikan.

Berdasarkan kendala tersebut, peneliti bersama kolabolator memberikan solusi melalui pemberian scaffolding, yaitu bimbingan secara khusus terhadap siswa yang dilakukan guru saat pembelajaran dengan memantau setiap siswa dalam menyelesaikan masalah. Pemberian scaffolding ini bertujuan agar guru dapat memberikan bantuan secara khusus sesuai dengan kesulitan yang dialami siswa.

Terakhir, pada tahap verification dan generalization, melalui hasil observasi 
ditemukan bahwa sebagian besar siswa belum yakin untuk menyampaikan pendapatnya mengenai jawaban yang telah diperoleh. Selain itu, siswa masih belum berani untuk menyimpulkan materi yang telah dipelajari sehingga tahap ini belum terlaksana secara optimal.

Peneliti bersama kolabolator memberikan solusi perbaikan yang dapat dilakukan untuk mengatasi kendala tersebut. Adapun solusi yang diberikan yaitu guru meyakinkan siswa terhadap langkahlangkah penyelesaian yang telah dilakukan melalui cross-check pada langkah-langkah penyelesaian masalah. Langkah ini diambil agar siswa tidak ragu-ragu dengan jawaban yang telah diperoleh. Selain itu, guru dapat memberikan penguatan berupa contoh dan bukan contoh agar siswa memiliki penguatan konsep yang baik dan yakin dengan jawaban yang telah diperoleh. Untuk mengoptimalkan sikap ketegasan dalam bertindak, guru melatih siswa untuk berani menyampaikan pendapat berupa kesimpulan tentang yang telah dipelajari.

Siklus II dilaksanakan pada 7 November 2019 dengan durasi 7 x 40 menit yang terbagi dalam tiga pertemuan dan 2 x 40 menit untuk tes prestasi belajar. Pada siklus II, peneliti masih bertindak sebagai guru yang melaksanakan pembelajaran dengan pendekatan guided discovery learning, sedangkan guru kelas bertindak sebagai observer.

Pada siklus II juga dilaksanakan dengan tahapan: perencanaan, pelaksanaan, pengamatan, dan refleksi. Tahap perencanaan, RPP dan LKPD disusun kembali dengan mempertimbangkan hasil refleksi pembelajaran pada siklus I. Kegiatan guru maupun kegiatan siswa yang belum terlaksana pada pembelajaran siklus I disusun kembali melalui RPP dan LKPD dengan menambahkan langkah solusi perbaikan yang diperoleh di tahap refleksi. Selain itu, peneliti bersama kolaborator menyiapkan kembali instrumen berupa soal tes prestasi belajar, angket self-confidence siswa serta lembar observasi keterlaksanaan pembelajaran untuk siklus II.

Tahap pelaksanaan, pembelajaran berlangsung sesuai dengan rancangan RPP dan LKPD yang telah dibuat. Pelaksanaan pembelajaran ini meliputi seluruh perbaikan pada hasil refleksi dari siklus I dilakukan agar mencapai hasil yang optimal. Setting kelas saat pembelajaran dilaksanakan secara berkelompok 3-4 siswa seperti pada siklus I.

Pada tahap pengamatan, guru matematika kelas VII mengamati kembali keterlaksanaan pembelajaran yang dilakukan oleh peneliti. Observasi dilakukan untuk mengetahui kembali keterlaksaan kegiatan guru $(\mathrm{KG})$ dan kegiatan siswa (KS) pada pembelajaran dengan guided discovery learning. Adapun hasil observasi keterlaksanaan pembelajaran siklus II disajikan pada Tabel 5 .

Pada tahap refleksi siklus II, peneliti bersama kolaborator melakukan evaluasi kembali terhadap hasil tes prestasi belajar siswa, keterlaksanaan pembelajaran, dan hasil angket self-confidence siswa.

Tabel 5

Hasil Keterlaksanaan Pembelajaran Siklus II

\begin{tabular}{ccc}
\hline Kegiatan & Hasil & Keterangan \\
\hline Kegiatan Guru (KG) & $89,17 \%$ & Tercapai \\
Kegiatan Siswa (KS) & $84,23 \%$ & Tercapai \\
\hline
\end{tabular}


Berdasarkan Tabel 3, hasil tes prestasi belajar siswa yang terdiri dari 5 butir soal uraian memperoleh ketuntasan siswa sebanyak $82 \%$ dengan nilai rata-rata 81,5 . Hasil tersebut lebih tinggi dibandingkan hasil tes prestasi belajar pada siklus I. Pelaksanaan pembelajaran memperoleh hasil 89,17 untuk kegiatan guru (KG) dan $84,23 \%$ untuk kegiatan siswa (KS). Nilai tersebut mengalami kenaikan sebesar 7,56\% dari capaian kegiatan siswa (KS) pada siklus I. Berdasarkan hasil tersebut, pelaksanaan pembelajaran pada siklus II telah mencapai minimum target keberhasilan yang telah ditetapkan, yaitu $80 \%$. Hasil angket self-confidence siswa pada siklus II mencapai skor ratarata 118,36 dengan kategori tinggi dengan kenaikan 4,43\% dari siklus I (Gambar 3). Dengan demikian, tes prestasi belajar, pelaksanaan pembelajaran, dan selfconfidence siswa telah memenuhi indikator keberhasilan pada penelitian ini sehingga penelitian ini berhenti pada siklus II.

Berdasarkan uraian hasil penelitian di atas, pembelajaran dengan mengoptimalkan pendekatan guided discovery learning dapat diterapkan dalam pembelajaran di kelas VII E untuk meningkatkan selfconfidence siswa.

Berdasarkan tahapan-tahapan pada guided discovery learning, penelitian ini dilaksanakan dengan beberapa upaya sehingga dapat meningkatkan self-confidence siswa. Pertama, tahap stimulation, perbaikan yang dilakukan pada tahap ini yaitu berupa pemberian masalah dengan model matematika intuitif. Siswa dihadapkan pada suatu masalah dan diharapkan memiliki keinginan untuk menyelidiki secara mandiri dan yakin dengan kemampuannya untuk menyelesaikan masalah.

Siswa diharapkan mampu memahami dengan mudah permasalahan yang dimaksud. Hasil penelitian Munir (2012, p. 252) menemukan bahwa model matematika yang disampaikan secara intuitif lebih mudah dipahami siswa secara penalaran matematis. Masalah dengan model intuitif matematis tersebut maksudnya pemberian masalah yang disusun secara bahasa

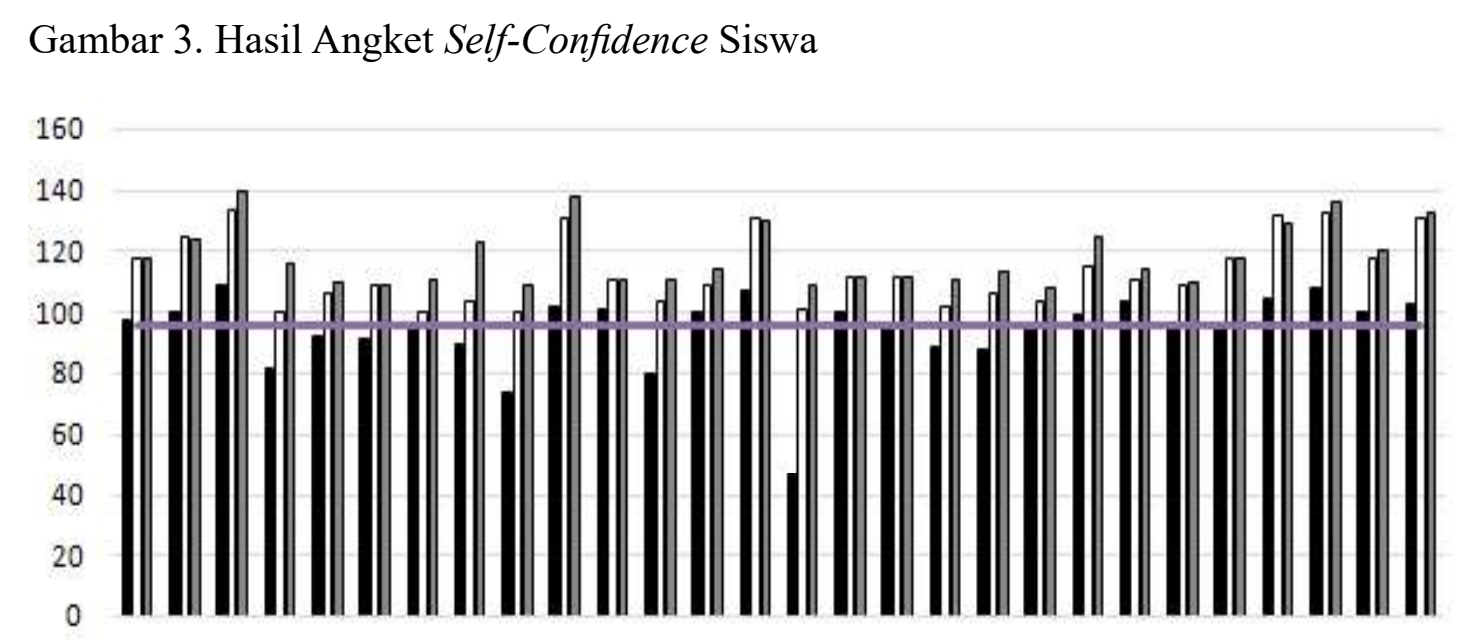

$\begin{array}{llllllllllllllllllllllllllll}1 & 2 & 3 & 4 & 5 & 6 & 7 & 8 & 9 & 10 & 11 & 12 & 13 & 14 & 15 & 16 & 17 & 18 & 19 & 20 & 21 & 22 & 23 & 24 & 25 & 26 & 27 & 28\end{array}$

Prasiklus $\square$ Siklus $1 \square$ Siklus $2-$ KKM 
dapat dipahami oleh siswa (Istiqlal, 2019) sehingga siswa dapat merumuskan masalah penyelidikan ke dalam ungkapan-ungkapan pertanyaan yang menghubungkan dua hal atau lebih yang saling berkaitan (Rasmawan, 2018).

Upaya lain yang dilakukan pada tahap ini adalah guru meminta siswa untuk membaca permasalahan yang diberikan. Upaya ini berfungsi untuk membantu siswa mengeksplorasi bahan materi-materi terkait yang ada pada permasalahan. Suatu permasalahan membutuhkan kemampuan koneksi siswa untuk menghubungkan materi dengan masalah sehingga dapat diperoleh solusi. Guru memberikan contoh dan bukan contoh terkait masalah agar siswa paham dengan konsep materi yang disampaikan. Eggen dan Kauchack (2012, p. 177) mengatakan bahwa dalam model guided discovery learning perlu memberi contoh-contoh permasalahan topik secara khusus untuk memandu dan membantu siswa memahami konsep untuk memecahkan masalah.

Dengan upaya-upaya tersebut, siswa mampu memiliki keyakinan terhadap kemampuan matematis dirinya dan terhadap masalah matematika. Siswa yang percaya diri pada kemampuan matematisnya akan memberikan usaha lebih dan yakin terhadap belajar matematika sehingga memiliki pemahaman dalam menyelesaikan masalah (Fadilla, Noer, \& Gunowibowo, 2017). Sikap percaya diri siswa pada matematika sebagai ilmu pengetahuan dapat diterima secara rasional dan realistik serta memberikan manfaat karena masalah kehidupan sehari-hari dapat dimodelkan berdasarkan kaidah matematika.

Kedua, tahap problem statement memiliki keterkaitan dengan keyakinan siswa terhadap kemampuan matematikanya untuk menyelesaikan masalah. Di tahap ini, guru memberikan bimbingan secara klasikal di depan kelas mengenai tahapan mengidentifikasi masalah. Hal ini dilakukan karena proses mengidentifkasi masalah adalah tahap awal dalam menyelesaikan masalah sehingga guru menjelaskan dengan memberikan petunjuk langkah-langkah untuk mengidentifikasi masalah (Syah, 2014, p. 245). Perbaikan ini dilakukan karena siswa memerlukan bimbingan dari guru agar siswa dapat mengikuti pada petunjuk yang guru berikan (Iltavia, 2019).

Ketiga, tahap data collection dan data processing fokus kepada siswa untuk mengumpulkan informasi sebanyakbanyaknya dari masalah tersebut dan mengolahnya secara realistik serta menafsirkan data sesuai dengan rasional mereka dalam belajar matematika. Perbaikan yang dilakukan pada tahap ini adalah pemberian scaffolding yang dilakukan guru secara berkeliling. Tujuannya agar guru dapat memberikan bantuan secara khusus sesuai dengan kesulitan yang dialami siswa sehingga tidak dapat diselesaikan dengan sendiri. Secara teori Vygotsky, scaffolding sebagai salah satu strategi dalam pembelajaran yang dapat membantu kognitif siswa, yaitu untuk menangani tugas-tugas/masalah yang menurut siswa sulit namun sebenarnya masih berada dalam jangkauan kemampuannya (Zone of Proximal Development/ZPD). Guru perlu menyediakan berbagai jenis dan tingkat bantuan (helps/ cognitive scaffolding) yang dapat memfasilitasi siswa agar mereka dapat memecahkan masalah yang dihadapi oleh masing-masing. Apriana, Maharta, dan Abdurrahman (2014) menemukan bahwa pemberian scaffolding memiliki pegaruh pada proses pemecahan masalah sehingga langkah ini tepat diberikan kepada siswa. Selain itu, Mahanani dkk. (2019) menyebutkan bahwa peran scaffolding yang diberikan guru selama 
proses pembelajaran merupakan salah satu faktor yang dapat meningkatkan keefektifan model pembelajaran inkuiri. Sesuai dengan teori Vygotsky, siswa perlu belajar secara berkelompok sehingga siswa dapat saling berinteraksi dan diperlukan bantuan guru terhadap siswa dalam kegiatan pembelajaran.

Keempat, pada kegiatan verification siswa melakukan pemeriksaan untuk membuktikan benar atau tidaknya hipotesis yang telah ditetapkan tadi dengan temuan alternatif. Di tahap ini, siswa diberikan kesempatan untuk menemukan suatu konsep, aturan, atau pemahaman (Syah, 2014, p. 247) melalui masalah-masalah yang telah mereka selesaikan. Apabila tahap verification dapat dilalui dengan baik, siswa merasa yakin dan optimis bahwa yang diperoleh merupakan jawaban yang benar. Fakta di lapangan, masih terdapat siswa yang merasa gelisah mengenai jawaban yang diperolehnya. Oleh karena itu, langkah perbaikan yang dilakukan guru pada tahap ini yaitu meyakinkan siswa terhadap langkah-langkah penyelesaian yang telah dilakukan melalui cross-check pada langkah-langkah penyelesaian. Pada proses penyelesaian masalah, tahap ini merupakan kegiatan evaluasi yang meliputi mengecek (checking) yaitu pengujian terhadap hal-hal yang tidak konsisten maupun kegagalan dari suatu operasi dan mengkritisi (critiquing) yaitu penilaian pada operasi berdasarkan standar (Tias \& Wutsqa, 2015). Langkah ini diambil peneliti yang mengacu pada langkah penyelesaian menurut Polya. Tahapan pemecahan masalah yang terpenting adalah memastikan bahwa jawaban merupakan solusi yang tepat dan benar. Berdasarkan langkah penyelesaian masalah menurut Polya, pengecekan ini mencakup keyword dari masalah, langkah penyelesaian masalah dan solusi dari masalah (Nurkaeti, 2018).
Hal ini dimaksudkan agar siswa tidak raguragu dengan jawaban yang telah diperoleh. Selain itu, guru juga memberikan penguatan berupa contoh dan bukan contoh. Penelitian Muhammad dan Karso (2018) menemukan bahwa pemberian contoh dan bukan contoh sebagai bentuk upaya untuk penguatan konsep sehingga siswa merasa yakin dengan jawaban yang diperoleh.

\section{SIMPULAN}

Berdasarkan hasil penelitian ini dapat disimpulkan bahwa self-confidence siswa di kelas VII E SMP Negeri 2 Yogyakarta berada pada kategori rendah sehingga diperlukan upaya peningkatan. Adapun upaya dalam meningkatkan selfconfidence siswa dilakukan dengan metode pembelajaran guided discovery learning yang setiap langkahnya telah dimodifikasi. Hal ini bertujuan agar setiap langkah pada guided discovery learning yang memiliki keterkaitan dengan setiap aspek selfconfidence lebih mudah untuk dilakukan upaya peningkatan. Adapun pembelajaran guided discovery learning yang dapat meningkatkan self-confidence siswa pada penelitian ini di antaranya: penyajian permasalahan matematika dengan model matematika intuitif pada langkah stimulation agar lebih mudah dipahami dan diprediksi hasilnya oleh siswa, pada langkah problem statement; guru memberikan bimbingan secara klasikal di depan kelas untuk membantu siswa mengidentifikasi masalah; guru memberikan bimbingan secara berkeliling, yaitu berupa scaffolding agar menemukan dan mengatasi kesulitan masing-masing siswa dalam proses mengumpulkan dan memproses data; dan guru meyakinkan siswa terhadap langkah-langkah penyelesaian melalui cross-check/evaluation berdasarkan kaidah penyelesaian sehingga siswa secara yakin mampu menemukan konsep 
dan berani menyampaikannya yang telah dipelajarinya.

\section{DAFTAR PUSTAKA}

Apriana, A., Maharta, N., \& Abdurrahman, A. (2014). Pengaruh scaffolding dalam pemecahan masalah fisika berbasis multirepresentasi terhadap hasil belajar siswa. Jurnal Pembelajaran Fisika, 2(1).

Azwar, S. (2012). Metode penelitian (ed. 2). Yogyakarta: Pustaka pelajar.

Cattaneo, K. H. (2017). Telling active learning pedagogies apart: From theory to practice. Journal of New Approaches in Educational Research, 6(2), 144-152.

Eggen, P., \& Kauchack, D. (2012). Strategi dan model pembelajaran. Jakarta: PT Indeks.

Fadilla, D. C., Noer, S. H., \& Gunowibowo, P. (2017). Efektivitas guided discovery learning ditinjau dari kemampuan representasi matematis dan seflconfidence. Jurnal Pendidikan Matematika Unila, 5(7), 815-829.

Ghufron, N., \& Risnawati, R. (2012). Teoriteori psikologi. Yogyakarta: Ar-Ruzz Media.

Hapsari, M. J. (2011). Upaya meningkatkan self-confidence siswa dalam pembelajaran matematika melalui model inkuiri terbimbing. Dalam Prosiding Seminar Nasional Matematika dan Pendidikan Matematika (pp. 337-345). FMIPA UNY, Yogyakarta.

Hopkins, D. (2008). A teacher's guided to classroom research $\left(4^{\text {th }} \mathrm{ed}\right)$. London, UK: McGraw Hill.

Hasugian, E. (2018). Meningkatkan hasil belajar matematika melalui penerapan model pembelajaran discovery learning. Edutainment: Jurnal Ilmu Pendidikan dan Kependidikan, 6, 44-67.
Iltavia. (2019). Pengembangan modul berbasis penemuan terbimbing pada materi fungsi pembangkit. Jurnal Kependidikan, 3(2), 236-248.

Istiqlal, M. (2019). Dukungan kemampuan intuitif dalam pemecahan masalah matematika. Jurnal Ilmiah Pendidikan Matematika, 4(2), 146-152.

Jana, P., Anisa, A., \& Fahmawati, N. (2020). Model discovery learning untuk meningkatkan kemampuan pemecahan masalah. Aksioma: Jurnal Program Studi Pendidikan Matematika, 9(1), 213-220.

Kurniasih, N. R. (2016). Pembelajaran matematika menggunakan model pembelajaran penemuan terbimbing pada siswa kelas VIII F SMP MBS Pleret Tahun Pelajaran 2016/2017. Seminar Nasional Pendidikan Matematika Ahmad Dahlan, 1, 171-177.

Liestya, A. D., Muchlis, E. E., \& Agustinsa, R. (2020). Perbandingan hasil belajar matematika antara model discovery learning dan ekspositori materi segiempat dan segitiga. Jurnal Pendidikan Matematika Raflesia, 5(2), 103-112.

Mahanani, I., Rahayu, S., \& Fajaroh, F. (2019). Pengaruh pembelajaran inkuiri berkonteks socioscientificissues terhadap keterampilan kritis dan scientific explanation. Jurnal Kependidikan, 3(1), 53-68.

May, B., \& Fray, R. (2010). The influence of emotion, confidence, experience and practice on the learning process in mathematics. Learning and Teaching Mathematics, 2010(8), 15-19.

Muhammad, G. M., \& Karso, K. (2018). Penerapan model guided discovery learning untuk meningkatkan pemahaman konsep matematis mahasiswa. Jurnal Eksakta Pendidikan, 2(2), 108-115. 
Munir. (2012). Model penalaran intuitif siswa dalam menyelesaikan masalah matematika. Prosiding Seminar Nasional Matematika dan Pendidikan Matematika (pp. 251-262). FMIPA UNY, Yogyakarta.

Nurkaeti, N. (2018). Polya's strategy: An analysis of mathematical problem solving difficulty in $5^{\text {th }}$ grade elementary school. Jurnal Pendidikan Dasar Kampus Cibiru, 10(2), 140-147.

Ott, L. E., Carpenter, T. S., Hamilton, D. S., \& LaCourse, W. R. (2018). Discovery learning: Development of a unique active learning environment for introductory chemistry. Journal of the Scholarship of Teaching and Learning, 18(4), 161-180.

Preston, D. I. (2007). 365 Steps to selfconfidence. UK: How to Book Ltd.

Rasmawan, R. (2018). Pengembangan LKS kimia berbasis inkuiri untuk meningkatkan keterampilan kerja ilmiah. Jurnal Kependidikan, 2(1), 98-115.

Smith, K. J., Grundmann, O., \& Li, R. M. (2018). The development and impact of active learning strategies on self-confidence in a newly designed first-year self-care pharmacy courseoutcomes and experiences. Currents in Pharmacy Teaching and Learning, 10(4), 499-504.

Sritresna, T. (2017). Meningkatkan kemampuan komunikasi matematis dan self-confidence siswa melalui model pembelajaran cycle 7E. Mosharafa, 6(3), 419-429.

Syah, M. (2014). Psikologi pendidikan dengan pendekatan baru. Bandung: PT Remaja Rosda Karya.

TIMSS [The Trends in International Mathematics and Science Study]. (2012). TIMSS 2011 International Results in Mathematics. Chestnut Hill: TIMSS \& PIRLS International Study Center.

Tias, A. A. W., \& Wutsqa, D. U. (2015). Analisis kesulitan siswa SMA dalam pemecahan masalah matematika kelas XII IPA di Kota Yogyakarta. Jurnal Riset Pendidikan Matematika, 2(1), 28-39.

Tran, T., Nguyen, N-G., Bui, M-D., \& Phan, A-H. (2014). Discovery learning with the help of the geogebra dynamic geometry software. International Journal of Learning, Teaching, and Educational Research, 7(1), 44-57.

Westwood, P. (2008). What teachers need to know about teaching methods. Camberwell, Victoria: ACER Press. 